\title{
Implementation of surveillance systems to determine the burden of communicable diseases in a facility in Qatar
}

\author{
Humberto Guanche Garcell, ${ }^{1}$ Tania Fernandez Hernandez, ${ }^{1}$ Elmousbasher Baker ${ }^{2}$ and Ariadna Villanueva Arias ${ }^{1}$
}

'The Cuban Hospital, Hamad Medical Corporation, Dukham, Qatar (Correspondence to: Humberto Guanche Garcell: humbertoguanchegarcell@yahoo. es; guanche@infomed.sld.cu). ${ }^{2}$ Public Health Department, Supreme Council of Health, Doha, Qatar

\begin{abstract}
Background: Hospital-based surveillance has proved useful in determining the incidence of infectious diseases.

Aims: This study aimed to describe the epidemiological characteristics of reported cases and specific performance indicators of the surveillance system.

Methods: A descriptive study of reported communicable diseases was carried out in The Cuban Hospital (Qatar) during January 2012 to December 2013. A multidimensional communicable diseases surveillance approach was used. Information of epidemiological variables, laboratory confirmation and notification date were collected. We calculated the proportion of cases with laboratory confirmation and time between the report by the physician and notification to the Supreme Council of Health.

Results: A total of 1065 patients were reported; 802 (75.3\%) male with a mean age of 33.2 (standard deviation 15.4) years. There was a predominance of cases from Southeast Asia (41.5\%) and Eastern Mediterranean Region (16.7\%). There were 539 cases of influenza-like illness, 186 of skin infectious diseases, 66 of scabies, 48 with multidrug-resistant organisms, and 39 cases of diarrhoea of presumed infectious etiology. A steady increase in laboratory confirmation was observed (mean 59.3\%). Timing for notification to the Supreme Council of Health was 1.88 (2.9) days.

Conclusion: The implemented hospital-based surveillance system was feasible and delivered important insights into the epidemiological characteristic of communicable diseases in a western community in Qatar.

Keywords: surveillance system, communicable disease, hospital-based surveillance, Cuban Hospital, Qatar

Citation: Guanche Garcell H; Fernandez Hernandez T; Baker E; Villanueva Arias A. Implementation of surveillance systems to determine the burden of communicable diseases in a facility in Qatar. East Mediterr Health J. 2019;25(11):813-819. https://doi.org/10.26719/emhj.19.023

Received: 01/06/14; accepted: 23/04/18

Copyright (c) World Health Organization (WHO) 2019. Some rights reserved. This work is available under the CC BY-NC-SA 3.0 IGO license https:// creativecommons.org/licenses/by-nc-sa/3.0/igo.
\end{abstract}

\section{Introduction}

The implementation of a surveillance system for community-acquired infections, in compliance with national regulations, has the main purpose of achieving timely and complete reporting of patients with infectious diseases (suspected or confirmed). This should contribute to knowledge of the incidence of communicable diseases in the population and early identification of outbreaks or epidemics, to facilitate timely prevention and control measures (1-3). Hospital-based surveillance systems have proved useful in determining the incidence of infectious and noninfectious diseases (4-7), and have been used as sentinel surveillance for selected health problems such as influenza and acute respiratory infections $(8-13)$. Studies that have focused on rotavirus gastroenteritis have shown high disease burden in Romania (14), Pakistan (15) and Ethiopia (16), and have emphasized the need for national immunization programmes. Biggs et al. (7) used a hospital-based sentinel surveillance system to identify a high incidence of leptospirosis in Tanzania.

The Cuban Hospital in Qatar was opened during mid2011. It is a 75-bed facility and member of the Hamad Medical Corporation, which provides health care to a population of 80000 inhabitants of an industrial area in Western Qatar. All the medical staff (physician, nurses and ancillaries) are Cuban nationals. The surveillance of communicable diseases in The Cuban Hospital began in January 2012, following procedures defined by the Department of Public Health of the Supreme Council of Health (17). The objective of this study was to describe the results of implementation of the surveillance system and the burden of communicable diseases in a community in Western Qatar, which will provide useful information for leaders (e.g. departmental heads, medical directors and senior consultants) and clinicians.

\section{Methods}

\section{Study design}

This was a descriptive study of communicable diseases reported at The Cuban Hospital during January 2012 to December 2013.

\section{Implementation of the surveillance system}

The hospital-based surveillance system, which focuses on community-acquired infections, is conducted by the Department of Infection Control, and includes a hospital epidemiologist, infection control nurse, and support 
from the Department of Microbiology at The Cuban Hospital.

The surveillance system includes the followings components.

1. Training of medical staff about the national surveillance system and the incidence of communicable diseases in Qatar and neighbouring countries.

2. Laboratory component consisting of:

(i) laboratory-based alert system by means of immediate notification (by telephone) of relevant cases to the infection control staff; and

(ii) weekly review of laboratory data to identify laboratory-confirmed or nonreported cases.

3. Notification to the Supreme Council of Health.

All cases are notified by fax, while those cases that require immediate notification (e.g., measles and dengue fever) are notified by telephone. The national surveillance system classifies diseases into those that require immediate notification (within 24 hours) by telephone or fax, and those that may be notified as soon as possible but not immediately (by fax). Diseases are classified according to their priority for reporting defined by the national surveillance system and the need to implement prompt control measures. The Centers for Disease Control and Prevention standard definitions are used for reporting (18). Review of the surveillance definitions and drafting a compendium of definitions for internal reference and use for the medical staff was developed. This is an internal document of the Cuban Hospital and can be requested by e-mail.

4. Data analysis and dissemination

(i) Data analysis is conducted by descriptive analysis of cases reported, and presented in tables and graphs, including descriptions of cases over time. For influenza-like illness, the seasonal distribution of cases and etiology are described.

(ii) Feedback to medical staff through a monthly epidemiological bulletin.

(iii) Distribution of epidemiological alerts issued by the Department of Public Health of the Supreme Council of Health or the Cuban Hospital Department of Infection Control according the national or regional public health events/alerts.

\section{Data collection}

The following information was recorded: age, sex, nationality, reported illness, laboratory confirmation and date of notification to the Supreme Council of Health. The World Health Organization (WHO) classification system according to geographical areas (Americas, Africa, Europe, Southeast Asia, Eastern Mediterranean and Western Pacific regions) was used to classify cases according to their nationality. Qatari nationals were analysed as a single group, and not included in cases reported in Eastern Mediterranean Region countries.

\section{Statistical analysis}

All information was analysed using JMP version 10.0 (http://www.jmp.com) using descriptive statistical techniques. The proportion of laboratory-confirmed cases was calculated per 100 reported cases.

\section{Results}

We reported 1065 patients with communicable diseases during the study period: $802(75.3 \%)$ male; mean age 33.2 (standard deviation 15.4) years (Table 1). Qatari patients represented $20.3 \%$ of reported cases. There were 442 (41.5\%) cases from Southeast Asia and 178 (16.7\%) from other Eastern Mediterranean Region countries, with other regions showing lower frequencies. The sex distribution highlights the predominance of male patients, which was $93.9 \%$ in Southeast Asia; mainly from India and Nepal.

There were 539 (50.6\%) patients reported with influenza-like illness, 186 with skin infectious diseases, 66 with scabies, 48 with multidrug-resistant infections, and 39 with diarrhoea of probable infectious etiology (39 cases). Additionally, 22 patients were reported with tuberculosis, 23 with malaria, 12 with sexually transmitted diseases (AIDS, gonorrhoea, syphilis and genital herpes simplex) and 2 with dengue fever, measles and rotavirus infection, respectively. "Others" included mainly severe respiratory tract infection or communityacquired pneumonia (not reported as influenza-like illness). No cases of acute flaccid paralysis, poliomyelitis, rubella, viral haemorrhagic fevers, anthrax, tetanus, diphtheria, mumps, pertussis, rabies, cholera or other epidemiologically important communicable diseases were reported.

Vaccine-preventable diseases (influenza and chickenpox) were the most frequent in patients from

\begin{tabular}{|c|c|c|c|}
\hline \multicolumn{4}{|l|}{$\begin{array}{l}\text { Table 1 Baseline chara } \\
\text { Hospital 2012-2013 }\end{array}$} \\
\hline \multirow[t]{2}{*}{ Variables } & \multirow[b]{2}{*}{ Total } & \multicolumn{2}{|c|}{ Sex } \\
\hline & & $\begin{array}{l}\text { Female } \\
n=263\end{array}$ & $\begin{array}{c}\text { Male } \\
n=802\end{array}$ \\
\hline Age, mean (SD), yr & $33.1(16.2)$ & $32.9(18.8)$ & $33.3(14.1)$ \\
\hline \multicolumn{4}{|l|}{ Nationality, $n$ (\%) } \\
\hline Qatari & 217 & $80(36.9)$ & $137(63.1)$ \\
\hline Other Eastern Mediterranean & 178 & $40(22.5)$ & $138(77.5)$ \\
\hline Southeast Asian & 442 & $27(6.1)$ & 415 (93.9) \\
\hline Western Pacific & 52 & $21(40.4)$ & $31(59.6)$ \\
\hline European & 31 & $12(38.7)$ & $19(61.3)$ \\
\hline African & 43 & $14(32.6)$ & $29(67.4)$ \\
\hline American & 102 & $69(67.6)$ & $33(32.4)$ \\
\hline
\end{tabular}




\begin{tabular}{|c|c|c|c|c|c|c|c|c|}
\hline Diseases & No. & Qatar & $\begin{array}{l}\text { Other Eastern } \\
\text { Mediterranean }\end{array}$ & $\begin{array}{l}\text { Southeast } \\
\text { Asia }\end{array}$ & Americas & Africa & Europe & $\begin{array}{c}\text { Western } \\
\text { Pacific }\end{array}$ \\
\hline Influenza-like illness & 539 & $120(22.3)$ & $74(13.7)$ & $252(46.8)$ & $26(4.8)$ & $21(3.9)$ & $13(2.4)$ & $33(6.1)$ \\
\hline Chickenpox & 25 & $1(4.0)$ & $1(4.0)$ & $23(92.0)$ & 0 & 0 & 0 & 0 \\
\hline Tuberculosis & 22 & 0 & 0 & $18(81.8)$ & 0 & $3(13.6)$ & 0 & $1(4.5)$ \\
\hline Measles & 2 & 0 & $1(50.0)$ & 0 & 0 & $1(50.0)$ & 0 & 0 \\
\hline Meningitis & 5 & $1(20.0)$ & $1(20.0)$ & $2(40.0)$ & 0 & 0 & $1(20.0)$ & 0 \\
\hline Severe acute respiratory infections & 8 & 0 & $1(12.5)$ & $4(50.0)$ & 0 & $1(12.5)$ & 0 & $2(25.0)$ \\
\hline Scarlet fever & 4 & $1(25.0)$ & $1(25.0)$ & $1(25.0)$ & 0 & $1(25.0)$ & 0 & 0 \\
\hline Skin infectious diseases & 189 & $35(18.5)$ & $32(16.9)$ & $42(22.2)$ & $56(29.6)$ & $7(3.7)$ & $9(4.8)$ & $8(4.2)$ \\
\hline Scabies & 66 & $12(18.2)$ & $17(25.8)$ & $27(40.9)$ & $3(4.5)$ & 0 & $2(3.0)$ & $5(7.6)$ \\
\hline Multidrug-resistant infections & 48 & $10(20.8)$ & $18(37.5)$ & $7(14.6)$ & $5(10.4)$ & $1(2.1)$ & $1(2.1)$ & $6(12.5)$ \\
\hline Viral hepatitis (acute/chronic) & 15 & $2(13.3)$ & $5(33.3)$ & $2(13.3)$ & $3(20.0)$ & 0 & $2(13.3)$ & $1(6.7)$ \\
\hline Sexually transmitted diseases & 12 & $2(16.7)$ & $3(25.0)$ & $1(8.3)$ & $3(25.0)$ & $1(8.3)$ & 0 & $2(16.7)$ \\
\hline Brucellosis & 2 & $2(100)$ & 0 & 0 & 0 & 0 & 0 & 0 \\
\hline Infectious diarrhoea & 39 & $9(23.1)$ & $3(7.7)$ & $20(51.3)$ & $1(2.6)$ & $2(5.1)$ & 0 & $4(10.3)$ \\
\hline Food poisoning & 12 & $7(58.3)$ & $4(33.3)$ & $1(8.3)$ & 0 & 0 & 0 & 0 \\
\hline Parasitic diseases & 11 & $1(9.1)$ & $2(18.2)$ & $5(45.5)$ & 0 & 0 & $1(9.1)$ & $2(18.2)$ \\
\hline Rotavirus infection & 2 & 0 & 0 & 0 & $1(50.0)$ & $1(50.0)$ & 0 & 0 \\
\hline Salmonellosis & 1 & 0 & 0 & $1(100)$ & 0 & 0 & 0 & 0 \\
\hline Typhoid fever & 4 & 0 & $1(25.0)$ & $2(50.0)$ & $1(25.0)$ & 0 & 0 & 0 \\
\hline Dengue & 2 & $1(50.0)$ & 0 & $1(50.0)$ & 0 & 0 & 0 & 0 \\
\hline Malaria & 23 & 0 & $10(43.5)$ & $10(43.5)$ & 0 & $3(13.0)$ & 0 & 0 \\
\hline Others & 34 & $13(38.2)$ & $4(11.8)$ & $9(26.5)$ & $3(8.8)$ & $1(2.9)$ & $2(5.9)$ & $2(5.9)$ \\
\hline
\end{tabular}

Southeast Asia (Table 2). Cases of viral hepatitis were primarily from other Eastern Mediterranean Region countries including Qatar; 2 of the patients from other Eastern Mediterranean Region countries had hepatitis B (from Oman and Morocco), and 3 had hepatitis C. The skin infectious diseases were predominantly fungal (46.0\%) and viral (42.0\%), and were mainly from Americas, Southeast Asia, Qatar and other Eastern Mediterranean Region countries. Scabies was primarily diagnosed in patients from Southeast Asia.

Southeast Asia accounted for 18 of 22 (81.8\%) tuberculosis patients; 16 from India and Nepal (Table 2). The other 4 patients were from African and the Western Pacific regions. Gastrointestinal infections (diarrhoea of infectious origin, parasitic diseases, salmonellosis and typhoid fever) were more frequently reported in Southeast Asia. Brucellosis (mainly related to exposure to camel's milk) and food poisoning were mainly reported in Qatar and other Eastern Mediterranean Region countries. Twenty-eight of 48 (58.3\%) cases of multidrug-resistant infections were from the Eastern Mediterranean Region countries (10 from Qatar, 8 from Pakistan, 5 each from Egypt and other countries).

Primary mode of transmission was respiratory $(62.2 \%)$, direct and indirect contact $(29.2 \%)$, fecal-oral (6.2\%) and vector borne (e.g., dengue and malaria) (2.4\%).
Probable etiology of the reported communicable diseases was viral $(67.7 \%)$, bacterial $(13.8 \%)$, parasitic (mainly scabies) (9.0\%), fungal (mostly skin infections) (8.2\%) and unknown (1.2\%). The basic etiology of malaria was Plasmodium vivax (20 patients), with 1 patient infected with Plasmodium falciparum and 2 with mixed P. vivax/ falciparum.

During the study period, a steady increase was observed in the laboratory confirmation of reported cases with a mean figure of $59.3 \%$ of confirmed cases, and a maximum figure during September 2013 of $(87.5 \%$ of cases) (Figure 1).

\section{Discussion}

The study provides a general picture of communicable diseases reported in a newly opened facility in Qatar. The incidence of infectious diseases is a reflection of the population characteristics (e.g., demographics and ethnicity) $(19,20)$ and related health systems issues (e.g. incidence of communicable diseases), especially the effectiveness of infection prevention and control programmes. The population from which our results came were predominantly workers in the oil industry, mostly from Southeast Asian countries, which have significant differences in the structure and function of their 


\section{Figure 1 Percentages of reported cases with laboratory confirmation, 2012-2013}

100

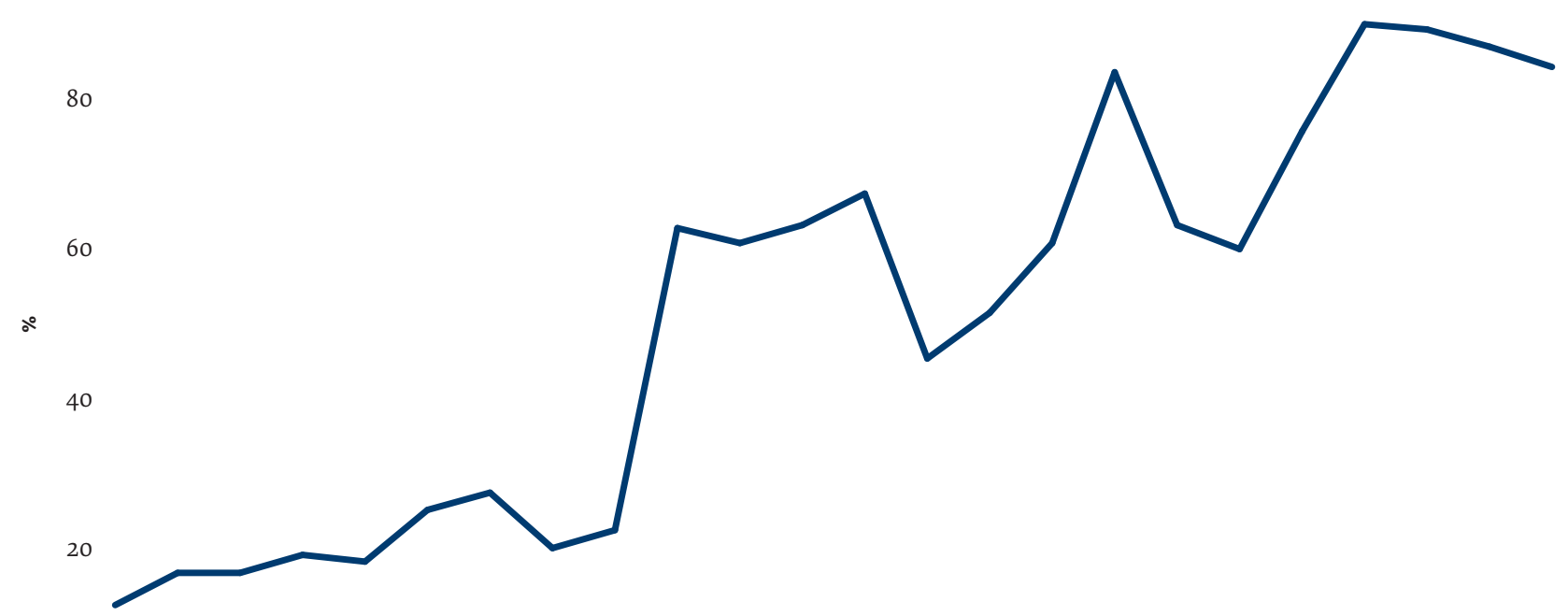

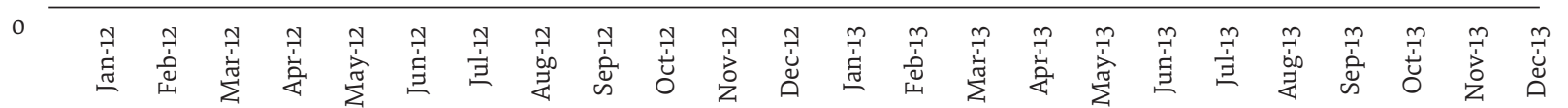

national health systems and incidence of infectious diseases when compared to Qatar (21).

Qatar has high vaccination coverage for major vaccine-preventable diseases, reaching between 93 and 98\% (22), which is similar to other Eastern Mediterranean Region countries, except Pakistan, which has < $90 \%$ coverage, and the presence of endemic poliomyelitis is a clear failure in their immunization programme. A similar problem arises in Southeast Asia, with frequent reports of measles and other vaccine-preventable diseases (23). Referring to hepatitis C, it is well known that Eastern Mediterranean Region countries have high population rates of chronic infection, mainly in Egypt (15\%) and Pakistan (4.8\%), due to exposure to injections with contaminated needles (24).

Data from Qatar relating to influenza (since 2011) can be found on the WHO website, which is based on the national laboratory surveillance system (25). The significant prevalence of reported cases of influenzalike illness is mainly due to the circulation of respiratory viruses in the community, and the contribution of climatic factors, especially the presence of dust from the desert. Influenza immunization coverage is probably low in Qatar, although there are no data about this issue.

The number of patients diagnosed with tuberculosis was small in our study, even though > 500 cases are reported annually, mainly from Southeast Asian countries, which have a high incidence of the disease (22). Similarly, gastrointestinal infections, especially typhoid fever and parasitic infections, are imported from these countries. Salmonellosis (non-typhoid) and food poisoning are related to specific risks in the food chain, especially in public markets.
Theincidence of sexually transmitted diseases in Qatar is low, similar to other Eastern Mediterranean Region countries and the countries of origin of the patients who attended the facility, which explained our findings. The significant prevalence of multidrug-resistant infections in the Eastern Mediterranean Region (including Qatar), even when there are no national reports about these, may be related to national and regional policies and practices of antimicrobial use in humans and animals, which is a topic that requires further study.

The frequent reporting in our study of infectious skin diseases, which include a wide variety of diseases of predominantly viral or fungal etiology, is related to surveillance strategies at the national level. We made special mention of scabies, which is more strongly related to personal hygiene and living conditions, and depends on the cultural, educational and socioeconomic factors of patients, who are generally unskilled workers.

The proportion of laboratory-confirmed cases constitute an indicator of system operation, which showed steady improvement during the study period as a result of the progressive increase in availability of laboratory resources and monitoring of systems operation.

The implementation of a surveillance system in a newly created facility is a challenge, and even greater when medical staff come entirely from a country with significant differences in surveillance methods and procedures. Furthermore, it is vital to educate the staff about the surveillance procedures and use of information about the incidence of infectious diseases at local or regional level, for clinical decision-making $(2,26)$.

The diseases under surveillance in the Cuban Hospital follow the recommendations of the Department 
of Public Health of the Supreme Council of Health, Qatar. However, monthly data analysis and feedback to the staff were performed at The Cuban Hospital, which is not usual practice in public healthcare facilities in Qatar.

There were some limitations to the present study. First was the limited possibility to compare the results with similar hospital-based studies conducted at national or regional levels. Second, there were small numbers of cases reported for some communicable diseases.

We believe that for the Qatari National Health System, the characteristics of the population are a challenge for epidemiological surveillance, which requires continuous analysis of surveillance strategies and methods for prevention and control of infectious diseases. The hospital-based surveillance system implemented was feasible and delivered important insights into the burden of communicable diseases in Western Qatar, which can be used for clinicians and leaders (e.g., departmental heads, medical directors and senior consultants) for improvement of public health.

Funding: None.

Competing interests: None declared.

\section{Mise en œuvre d'un système de surveillance pour déterminer la charge des maladies transmissibles dans un établissement de santé au Qatar}

\section{Résumé}

Contexte : La surveillance en milieu hospitalier s'est révélée utile afin de déterminer l'incidence des maladies infectieuses. Objectif : Décrire les caractéristiques épidémiologiques de cas rapportés et les indicateurs d'exécution spécifiques du système de surveillance.

Méthodes : Une étude descriptive des maladies transmissibles notifiées a été réalisée au sein du Cuban Hospital (Qatar) de janvier 2012 à décembre 2013. Une approche pluridimensionnelle de la surveillance des maladies transmissibles a été utilisée. Des informations ont été collectées sur les variables épidémiologiques, la confirmation en laboratoire et la date de notification. Nous avons calculé la proportion de cas avec confirmation en laboratoire, ainsi que les délais entre le rapport du médecin et la notification au Conseil Supérieur de la santé (CSS).

Résultats : 1065 patients au total ont été signalés ; dont 802 (75,3\%) hommes d'une moyenne d'âge de 33,2 ans (écart type 15,4). Une prédominance de cas provenait d'Asie du Sud-Est (41,5\%) et de la Région de la Méditerranée orientale (16,7\%). Cinq cent trente-neuf (539) cas de syndrome de type grippal, 186 cas de maladies infectieuses de la peau, 66 cas de gale, 48 cas impliquant des micro-organismes multirésistants et 39 cas de diarrhées d'origine présumée infectieuse ont été enregistrés. Une augmentation régulière des confirmations en laboratoire a été observée (moyenne de 59,3\%). Le délai de notification au CSS était de 1,88 (2,9) jours.

Conclusion : Le système de surveillance mis en œuvre en milieu hospitalier était réalisable et fournissait des indications importantes sur les caractéristiques épidémiologiques des maladies transmissibles au sein d'une communauté occidentale du Qatar.

$$
\begin{aligned}
& \text { تطبيق نظام الترصد وعبء الأمر اض السارية في أحد المر افق في قطر } \\
& \text { هومبرتو جارسيل، تانيا هيرنانديز، المبشر بكر، أريادنا أرياس } \\
& \text { الخلاصة } \\
& \text { الخلفية: لقد ثبت أن الترصد القائم على المستشفيات مفيد في تحديد معدل الإصابة بالأمر اض المعدية. } \\
& \text { الأهداف: وصف الخصائص الوبائية للحالات المُبلغ عنها ومؤشرات أداء معينة لنظام الترصد. }
\end{aligned}
$$

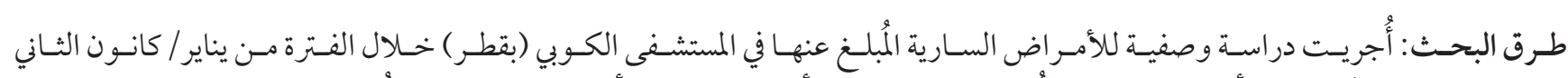

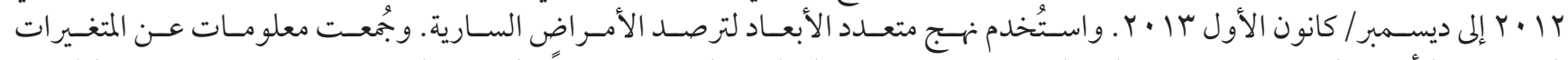

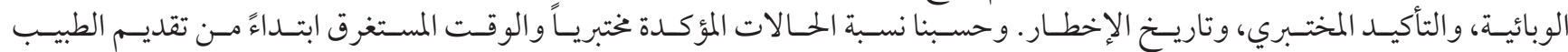

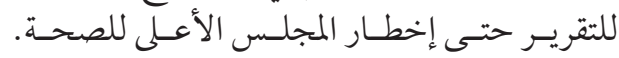




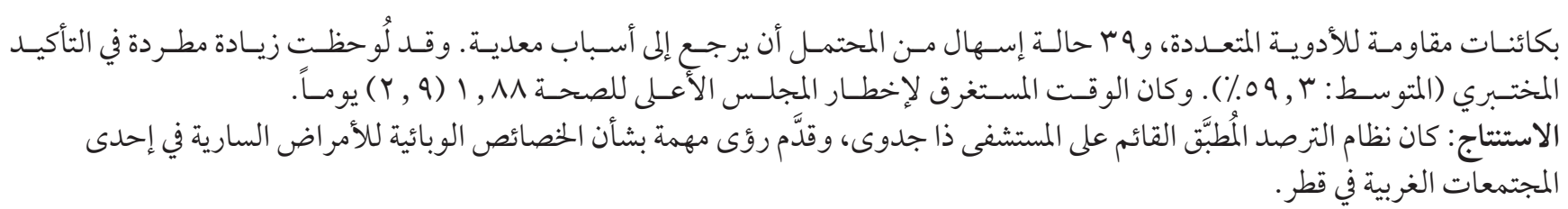

\section{References}

1. Communicable disease surveillance and response systems. Guide to monitoring and evaluating. World Health Organization; 2006 (https://www.who.int/csr/resources/publications/surveillance/WHO_CDS_EPR_LYO_2006_2.pdf?ua=1, accessed 9 April 2019).

2. Beuhler JW, Centers for Disease Control and Prevention. CDC's vision for public health surveillance in the 21st century. MMWR Suppl. 2012 Jul 27;61(3):1-2. PMID:22832989

3. German RR, Lee LM, Horan JM, Milstein RL, Pertowski CA, Waller MN. Updated guidelines for evaluating public health surveillance systems: recommendations from the guidelines working group. MMWR Recomm Rep. 2001 Jul 27;50(RR-13):1-35. PMID:18634202

4. Konstantopoulos A, Tragiannidis A, Fouzas S, Kavaliotis I, Tsiatsou O, Michailidou E, et al. Burden of rotavirus gastroenteritis in children <5 years of age in Greece: hospital-based prospective surveillance (2008-2010). BMJ Open. 2013 Dec 11;3(12):e003570. http://dx.doi.org/10.1136/bmjopen-2013-003570 PMID:24334153

5. Wainigolo I, Kafoa B, McCaig E, Kool B, McIntyre R, Ameratunga S. Development and piloting of the Fiji Injury Surveillance in Hospitals System (TRIP Project-1). Injury. 2013 Jan;44(1):126-131. http://dx.doi.org/10.1016/j.injury.2011.10.007 PMID:22098715

6. Bonney JHK, Osei-Kwasi M, Adiku TK, Barnor JS, Amesiya R, et al. Hospital-based surveillance for viral hemorrhagic fevers and hepatitis in Ghana. PLoS Negl Trop Dis. 2013 Sep 19;7(9) e2435. http://dx.doi.org/10.1371/journal.pntd.0002435 PMID:24069490

7. Biggs HM, Hertz JT, Munishi OM, Galloway RL, Marks F, et al. Estimating leptospirosis incidence using hospital-based surveillance and a population-based health care utilization survey in Tanzania. PLoS Negl Trop Dis. 2013 Dec 5;7(12): e2589. http:// dx.doi.org/10.1371/journal.pntd.0002589 PMID:24340122

8. Lutwama JL, Bakamutumaho B, Kayiwa JT, Chiiza R, Namagambo B, Katz MA, et al. Clinic- and Hospital-Based Sentinel Influenza Surveillance, Uganda 2007-2010. J Infect Dis. 2012 Dec 15; 206(Suppl 1):S87-93. http://dx.doi.org/10.1093/infdis/jis578 PMID:23169978

9. Mmbaga VM, Mwasekaga MJ, Mmbuji P, Matonya M, Mwafulango A, Moshi S, et al. Results from the first 30 months of national sentinel surveillance for influenza in Tanzania, 2008-2010. J Infect Dis. 2012 Dec 15;206(Suppl 1):S80-6. http://dx.doi. org/10.1093/infdis/jis540 PMID:23169977

10. Nachtnebel M, Greutelaers B, Falkenhorst G, Jorgensen P, Dehnert M, Schweiger B, et al. Lessons from a one-year hospital-based surveillance of acute respiratory infections in Berlin- comparing case definitions to monitor influenza. BMC Public Health. 2012 Mar 27;12:245. http://dx.doi.org/10.1186/1471-2458-12-245 PMID:22452874

11. Julesa A, Grijalvaa CG, Zhub Y, Talbotc KH, Williams JV, Dupontb WD, et al. Estimating age-specific influenza-related hospitalization rates during the pandemic (H1N1) 2009 in Davidson Co, TN. Influenza Other Respir Viruses. 2012 May;6(3): e63-e71. http://dx.doi.org/10.1111/j.1750-2659.2012.00343.x PMID:22360812

12. Moorthy M, Samuel P, Peter JV, Vijayakumar S, Sekhar D, Verghese VP et al. Estimation of the burden of pandemic(HiN1)2009 in developing countries: experience from a tertiary care center in South India. PLoS One. 2012;7(9):e41507. http://dx.doi. org/10.1371/journal.pone.0041507 PMID:22957015

13. Baggett HC, Chittaganpitch M, Thamthitiwat S, Prapasiri P, Naorat S, Sawatwong P et al. Incidence and epidemiology of hospitalized influenza cases in rural Thailand during the influenza A (H1N1)pdmog pandemic, 2009-2010. PLoS One. 2012;7(11):e48609. http://dx.doi.org/10.1371/journal.pone.0048609 PMID:23139802

14. Anca IA, Furtunescu FL, Pleşca D, Streinu-Cercel A, Rugină S, Holl K. Hospital-based surveillance to estimate the burden of rotavirus gastroenteritis in children below five years of age in Romania. Germs. 2014 Jun 2;4(2):30-40. http://dx.doi.org/10.11599/ germs.2014.1053 PMID:24967217

15. Kazi AM, Warraich GJ, Qureshi S, Qureshi H, Khan MM, Zaidi AK et al. Sentinel hospital-based surveillance for assessment of burden of rotavirus gastroenteritis in children in Pakistan. PLoS One. 2014 Oct 8;9(10):e108221. http://dx.doi.org/10.1371/journal. pone.0108221 PMID:25295613

16. Abebe A, Teka T, Kassa T, Seheri M, Beyene B, Teshome B, et al. Hospital-based surveillance for rotavirus gastroenteritis in children younger than 5 years of age in Ethiopia: 2007-2012. Pediatr Infect Dis J. 2014 Jan;33(Suppl 1):S28-33. http://dx.doi. org/10.1097/INF.0000000000000048 PMID:24343610

17. State of Qatar. Ministry of Public Health [website] (https://www.moph.gov.qa/pages/default.aspx, accessed 7 May 2019).

18. National Notifiable Disease Surveillance System (NNDSS). Center for Disease Control and prevention [website] (http://wwwn. cdc.gov/nndss/default.aspx, accessed 9 April 2019). 
19. State of Qatar, Statistics Authority. Census of population and housing and establishments 2010 (https://www.mdps.gov.qa/en/ statistics/Statistical\%20Releases/General/Census/Population_Households_Establishment_QSA_Census_AE_2010_1.pdf, accessed 7 May 2019).

20. Qatar Population Status, 2012. Three years after launching the population policy (https://www.ppc.gov.qa/Admin/Reports/PPC_ Annual_Report_2011_EN.pdf, accessed 30 January 2014.

21. Global Health Observatory. Country statistics [website] (http://www.who.int/gho/countries/en/, accessed 7 May 2019).

22. Annual Report, 2012/2013. Changing lives for the better. Doha: Hamad Medical Corporation (https://www.hamad.qa/EN/ Our-Publications/Annual-Reports/Annual\%20Report\%202016/en/pdf/HMC_Download_Full_Report_12.pdf, accessed 7 May 2019.

23. WHO vaccine-preventable diseases: monitoring system. 2018 global summary [website]. World Health Organization; 2019 (https://apps.who.int/immunization_monitoring/globalsummary, accessed 7 May 2019.

24. Hepatitis C [website]. World Health Organization; 2019 (http://www.who.int/mediacentre/factsheets/fs164/es/, accessed 9 April 2019) (in Spanish).

25. Influenza FluNet [website]. World Health Organization; 2019 (https://www.who.int/influenza/gisrs_laboratory/flunet/en/, accessed 7 May 2019.

26. Choi BC. The past, present, and future of public health surveillance. Scientifica (Cairo). 2012;2012:875253. http://dx.doi. org/10.6064/2012/8752 PMID:24278752 